PART I. DISEASES AND PROBLEMS DISTINGUISHED BY THE WHO AND FAO DZIAŁ I. CHOROBY I PROBLEMY WYRÓŻNIONE PRZEZ WHO I FAO

\title{
EFFECT OF SELENIUM ON LARGE INTESTINE AND LUNG CANCER IN HUMANS - PART II
}

\section{WPŁYW SELENU NA ZAPOBIEGANIE NOWOTWOROM PRZEWODU POKARMOWEGO I PŁUC - CZĘŚĆ II}

\author{
Katarzyna Sygit $^{1(\mathrm{~B}, \mathrm{D}, \mathrm{E}, \mathrm{F}, \mathrm{G})}$, Krzysztof Sieja ${ }^{2(\mathrm{~A}, \mathrm{~B}, \mathrm{C})}$, Marian Sygit $^{3(\mathrm{~B}, \mathrm{D}, \mathrm{E}, \mathrm{F})}$ \\ ${ }^{1}$ Health Promotion Department, Faculty of Physical Culture and Health Promotion, University of Szczecin, Poland \\ ${ }^{2}$ Institute of Physical Culture, State Higher Vocational School in Wałcz, Poland \\ ${ }^{3}$ Physical Education Department, Faculty of Physical Culture and Health Promotion, Universty of Szczecin, Poland
}

\author{
Authors' contribution \\ Wkład autorów: \\ A. Study design/planning \\ zaplanowanie badań \\ B. Data collection/entry \\ zebranie danych \\ C. Data analysis/statistics \\ dane - analiza i statystyki \\ D. Data interpretation \\ interpretacja danych \\ E. Preparation of manuscript \\ przygotowanie artykułu \\ F. Literature analysis/search \\ wyszukiwanie i analiza literatury \\ G. Funds collection \\ zebranie funduszy
}

\author{
Tables: 0 \\ Figures: 0 \\ References: 26 \\ Submitted: 2018 Feb 02 \\ Accepted: 2018 March 15
}

\section{Summary}

Background. Persistently high incidence of 'diseases of affluence' (including cancer) motivates numerous research teams to look for causes of morbidity, as well as to search for preventive methods and effective therapeutic measures. The paper aims to present the literature on effects of selenium (Se) on prevention of gastrointestinal and lung cancer.

Material and methods. Based on national and international literature, the paper presents information on the role of selenium (Se) in prevention of cancer - with special consideration given to gastrointestinal and lung cancer.

Results. The results of national and international research show the importance of selenium in prevention and treatment of cancerous diseases, including digestive tract cancer and lung cancer. Numerous studies have shown that the risk of cancer for people with low selenium levels is twice as high as for people with high levels of selenium in blood serum. The most prominent relationship between low selenium level in serum and cancer is observed in gastrointestinal cancer, lung cancer, breast cancer in women, and prostate cancer.

Conclusions. Many clinical and experimental studies carried out nationally and internationally gathered evidence which indicate the vital role played by selenium in prevention and treatment of diseases - especially of cancer. It should be emphasised that the intake of selenium in amounts necessary for proper functioning - given numerous deficiencies (first in the soil, then in food products coming from selenium-deficient soil) - is merely the first step, as it has already been proven in numerous publications that carbohydrates (especially simple sugars, sweets, cakes, etc.) 'destroy' selenium in the human body.

Keywords: selenium, cancer, lung cancer, digestive tract cancer, prevention

\section{Streszczenie}

Wprowadzenie. Wysoka zachorowalność na choroby cywilizacyjne (w tym na choroby nowotworowe) skłania liczne zespoły badawcze do poszukiwania odpowiedzi dotyczacej przyczyn zachorowalności na nowotwory, jak i poszukiwania metod prewencji i skutecznych środków terapeutycznych. Celem niniejszej pracy jest przedstawienie w świetle literatury przedmiotu wpływu selenu (Se) na zapobieganie nowotworom przewodu pokarmowego i płuc. Materiał i metody. W pracy zaprezentowano na przykładzie dostępnej literatury przedmiotu (krajowej jak i zagranicznej) informacje dotyczące roli selenu (Se) w profilaktyce chorób nowotworowych - ze szczególnym uwzględnienie chorób nowotworowych przewodu pokarmowego i płuc..

Wyniki. Wyniki badań krajowych i światowych pokazują jak ogromne znaczenie ma wpływ selenu w profilaktyce i leczeniu chorób nowotworowych, w tym: przewodu pokarmowego i płuc. Liczne badania wykazały, że ryzyko raka dla osób z niskim poziomem selenu jest dwa razy większe niż dla osób z wysokim poziomem selenu w surowicy krwi. Najwyraźniejszy związek między niskim poziomem selenu w surowicy krwi a nowotworami jest dla nowotworów przewodu pokarmowego, płuc, gruczołu piersiowego u kobiet i prostaty.

Wnioski. W wielu badaniach klinicznych i eksperymentalnych przeprowadzonych w kraju i na świecie zebrano dowody wyraźnie wskazujące na duża role, jaka odgrywa Se dla profilaktyki i leczenia, zwłaszcza chorób nowotworowych. Podkreślić należy, że dostarczenie do organizmu Se w ilości niezbędnej do prawidłowego jego działania, w sytuacji licznych niedoborów (najpierw w glebie, potem w produktach spożywczych pochodzących z gleb z niedoborem Se) jest tylko pierwszym krokiem, gdyż udowodniono już w licznych publikacjach, że węglowodany (a zwłaszcza cukry proste, słodycze, ciasta itp.) spożywane „niszczą" selen w organizmie człowieka.

Słowa kluczowe: selen, choroba nowotworowa, nowotwór płuc, nowotwór przewodu pokarmowego, prewencja

Sygit K, Sieja K, Sygit M. Effect of selenium on large intestine and lung cancer in humans - part II. Health Prob Civil. 2018; 12 (3): 139-143. https://doi.org/10.5114/hpc.2018.74587

Address for correspondence / Adres korespondencyjny: Katarzyna Sygit, Department of Health Promotion, Faculty of Physical Education and Health Promotion, University of Szczecin, Poland, Cukrowa 12, 71-004 Szczecin, Poland, e-mail: katarzyna.sygit@usz.edu.pl, phone: +48914443492

Copyright: (C) Pope John Paul II State School of Higher Education in Biała Podlaska, Katarzyna Sygit, Krzysztof Sieja, Marian Sygit. This is an Open Access journal, all articles are distributed under the terms of the Creative Commons Attribution-NonCommercial-ShareAlike 4.0 International (CC BY-NC-SA 4.0) License (http:// creativecommons.org/licenses/by-nc-sa/4.0/), allowing third parties to copy and redistribute the material in any medium or format and to remix, transform, and build upon the material, provided the original work is properly cited and states its license. 


\section{Introduction}

In the 1960s, attention was drawn for the first time to the correlation between selenium deficiency and the risk of cancer, based on previous epidemiological work indicating co-occurrence of certain cancers and deficiency of selenium in soil in specific areas [1,2].

Höghberg and Alexander in their monograph devoted to selenium (pub. 2007), collected a whole series of epidemiological data, developed by other epidemiologists and reported that the high supply of selenium in food translates into a lower incidence of some cancers, among others lung cancer [3]. The protective role of selenium in carcinogenesis has been confirmed in numerous experiments that have shown inhibition of the initial (early) stages of this process $[4,5]$.

Presently, a whole range of signalling pathways is suggested that could potentially provide some insight into how selenium can block cell progression and induce their death [6].

Research by Willet et al. showed that the risk of cancer for individuals with low selenium levels is twice as high as for those with high levels of selenium in their blood serum [7,8]. The most prominent relationship between low selenium level in serum and cancer was observed in gastrointestinal cancer, lung cancer, breast cancer in women, and prostate cancer [9]. The following paper aims to present the literature on effects of selenium (Se) on prevention of gastrointestinal and lung cancer.

\section{Selenium versus large intestine cancer}

A large group of cancers (after breast cancer), for which the relationship between selenium and development of cancer is sought, are cancers of the gastrointestinal tract, especially of the large intestine. The development of large intestine cancer in first-degree relatives (parents, children, siblings) under the age of 40 indicates the possibility of a genetic condition of cancer. Colonoscopy is recommended for other members of the immediate family (ideally before the age of 40), as well as consultation with a Genetic Clinic. The most common causes of hereditary cancer of the large intestine are mutations in the APC gene or the DNA repair genes. Research by Yu et al. showed that selenium reduces the incidence of developing an experimentally-induced large intestine cancer in Wistar rats and interferes with a high-fat diet that affects the development of this type of cancer [10]. These results correlate with earlier research by Reddy and Tanaki [11].

Mikac - Devic et al., based on their research and studies conducted by other research groups, analysed the level of selenium in blood serum in large intestine cancer cases and concluded that significant differences in selenium level in serum of patients with large intestine cancer - in comparison to healthy individuals - justify the use of this micronutrient as a marker for large intestine cancer [12]. Additionally, Clark et al. showed that a decreased selenium concentration in serum may be a significant risk factor for polyp changes in the large intestine [13].

Epidemiological studies conducted in Shanxi province, China, on a substantial clinical material showed that selenium concentration levels in serum were significantly lower in a group of patients with large intestine cancer, compared to a healthy control group [14].

It should be noted that there are also relatively few reports in the literature whose authors did not find lower selenium concentration in people with cancer $[15,16]$.

Research by Schober and colleagues did not support the relationship between low levels of vitamin A and E, and selenium concentration in serum (and subsequent increased risk of developing large intestine cancer) [15]. Furthermore, in a study published in 1995, Nelson et al. did not find a protective effect of higher selenium concentration in serum on the occurrence of malignant or benign tumours of the large intestine [16].

Many transplantable tumours are insensitive to selenium. The cause of this phenomenon is not yet clarified, although Medina and Lane stated that it results from the differences in the existing inverse correlation between selenium concentration in serum and cancer risk in particular types of cancer. The strongest relation between selenium concentration in the body and the risk of cancer is shown by studies conducted to demonstrate GSH-P ${ }_{\mathrm{x}}$ activity in various types of cancer [17].

Generally, it may be concluded that undoubtedly there is a relation between low selenium concentration and an increased risk of cancer. However, there may be differences in optimal selenium levels for particular populations or countries [18]. For example, in the United States, the level of selenium associated with the lowest risk of colorectal adenomas is $\geq 150 \mu \mathrm{g} / \mathrm{l}$. Such differences between Europe and the United States may be associated with a number of genetic and environmental factors, including exposure to chemical agents $[15,18]$. 


\section{Selenium versus lung cancer}

The main reason for lung cancer is inhalation of carcinogens contained in cigarette smoke. This covers 80$90 \%$ of cases. Amongst non-smokers, lung cancer is rare. Lung cancer develops as a result of a very long biological process. It rarely appears in smokers who smoked for only ten years. The 'delay' between the start of smoking and the onset of the disease is 20,30 or even 40 years. Currently, Poland has the lowest rate of smokers in the last 50 years. Unfortunately, cigarettes are still smoked by $28 \%$ of men and $18 \%$ of women.

Several prospective studies identified an inverse association between selenium concentration and the risk of lung cancer $[3,19]$.

As experimental work by Liu et al. suggests, selenium plays an outstanding role in prevention and inhibition of proliferation not only of breast and prostate cancer but also of lung cancer. Objective studies showed that methylselenic acid displays anti-cancer activity. Methylselenic acid (MSA) can significantly inhibit proliferation and ability to form metastases in the L9981 cell line of highly metastatic lung cancer, as well as induce apoptosis. The anti-cancer effect of MSA may be associated with regulation of expression related to cell cycle related genes, and genes associated with apoptosis in humans with highly metastatic lung cancer of the L9981 cell line [20].

Available literature clearly indicates that the identification of low selenium concentrations may be very helpful in selecting patients for control exams, such as computed tomography, aimed at early detection of lung cancers. Over 20 studies have shown that low selenium levels in serum are associated with an increased likelihood of lung cancer. Studies conducted by the International Hereditary Cancer Centre in Szczecin, in which serum concentrations in the serum of 86 subjects with lung cancer and 86 healthy individuals were assessed, also showed a strong correlation between the amount of selenium and lung cancer [21].

Among lung cancer cases, the average selenium level was $63.2 \mu \mathrm{g} / \mathrm{l}$, compared to the average level of 74.6 $\mu \mathrm{g} / \mathrm{l}$ in the control group $(\mathrm{p}<0.0001)$. Among throat cancer patients, the average selenium level was 64.8 $\mu \mathrm{g} / \mathrm{l}$, compared to the average level of $77.1 \mu \mathrm{g} / \mathrm{l}$ in the control group $(\mathrm{p}<0.0001)$. There was also a $10 \mathrm{x}$ lower incidence of lung cancer in patients with selenium level in serum of $>80 \mu \mathrm{g} / \mathrm{l}$, compared to those with selenium concentration of $<60 \mu \mathrm{g} / \mathrm{l}$.

In the above-mentioned comparison, patients displayed an approximately $3 x$ lower incidence of laryngeal cancer accompanied by a higher selenium concentration in serum. The comparison of selenium level in serum of $<60 \mu \mathrm{g} / \mathrm{l}$ with $>80 \mu \mathrm{g} / \mathrm{l}$ was linked to the odds ratio 0.1 for lung cancer and 0.23 for laryngeal cancer [22]. Individuals in the study group and control group were selected with regard to age, gender and smoking addiction. The risk of developing both the lung cancer and laryngeal cancer decreased along with increased selenium concentration in the blood, and this relation appears to be linear. It should be emphasised that the average selenium level in the Polish population is $75.8 \mu /$ l. This level is far lower than the optimal level, which according to Rayman's proposition should be $120 \mu \mathrm{g} / \mathrm{l}$ since that level would allow optimal expression and activity of selenoproteins [23].

Thus far, a whole series of studies assessing the impact of selenium on the risk of lung cancer was carried out. Four studies showed selenium's protective effect against lung cancer, other four studies did not show such relationship, while two other studies showed an adverse effect of higher doses of selenium on lung cancer incidence [22]. However, it must be emphasised that the comparison of the above-mentioned study results is very difficult. The studies differed in terms of plans and designs (population studies, specific control groups, with or without selenium supplementation), high/low initial selenium level in the population, selenium measurement methods (dietary intake of selenium, determination of selenium concentration in serum or nails) and the length of the observation period [14].

Among the publications, the most cited one is a meta-analysis of 16 studies on the relationship between selenium and lung cancer, made by Zhuo et al. [14]. These authors showed in their collective analysis a relative risk of 0.74 for individuals with high exposure to selenium, i.e. these people had a smaller chance of developing lung cancer. However, this protective effect was more significant for individuals with lower average selenium level ( $R R=0.72$ ), who came from regions with low selenium concentration in soil, than for subjects from areas with higher concentration of selenium in soil, who had a higher average level of selenium in their blood serum $(\mathrm{RR}=0.86)$.

The results of this comparison correlate with the results obtained by the authors of a project entitled: Nutritional Prevention of Cancer Trial (NPC). The project confirmed that the protective effect of selenium may be limited to people with low baseline (pre-study) selenium level in blood. The study was conducted on 1,312 Americans who received $200 \mu \mathrm{g}$ /day of selenium or placebo in a randomised trial. In the follow-up study after 7.9 years, the odds ratio for the incidence of lung cancer was 0.70 . The beneficial effect, to a large extent, was limited to those with a low baseline selenium level, as per the American population $(<106 \mu \mathrm{g} / \mathrm{l})$. In this subgroup 
of subjects, the correlation between selenium supplementation and a lower risk of lung cancer was the strongest, and the odds ratio was 0.42 . This protective effect occurred only in men with a basic PSA level in serum of $\leq 4 \mu \mathrm{g} /$ $\mathrm{ml}$. and whose level of PSA in the blood was low (less than $123.2 \mu \mathrm{g} / \mathrm{ml}$ ) [24].

It should be noted, however, that a clinical trial entitled: The Selenium and Vitamin E Cancer Prevention Trial (SELECT) published in 2009 in the JAMA journal, found no benefits for men in a randomised trial who were given $200 \mu \mathrm{g}$ of selenium per day versus placebo in terms of the incidence of lung cancer (RR 1.12). However, in that study, the mean baseline level of selenium was $137 \mu \mathrm{g} / \mathrm{l}$, and the study results were not divided in terms of selenium in blood serum [25].

In 2008-2011 in Szczecin, an Early Pulmonary Detection Programme was carried out. The programme involved participants of both sexes, aged 55-65, with a history of tobacco smoking equal to at least 20 pack-years. The most recent addition to the protocol of this programme (in 2012) was adding pre-selection of participants in the form of measurement of selenium concentration in their blood serum. Only those with low selenium levels $(<75 \mu \mathrm{g} / \mathrm{l})$ were invited for computed tomography. This resulted in more than two-fold increase in the detection of lung cancer. The inclusion of selenium level in serum into prophylactic examinations for lung cancer yields tangible clinical and economic effects [26].

\section{Conclusions}

Many clinical and experimental studies conducted nationally and internationally gathered evidence which indicates the important role played by selenium in prevention and treatment of diseases - especially of cancer.

The search for factors causing the formation of cancer, as part of the epigenetic research, was largely focused on demonstrating the role of micronutrients (especially selenium). Many aspects have been clarified, but there is still a need for observational and diagnostic studies to clarify many issues raising doubts, as indicated for example in Cochrane Database of Systematic Reviews.

Several clinical and experimental animal tests suggest that improving the supply of selenium to the body may reduce the incidence of several types of cancer, such as lung, colon and breast cancer. The results of recent clinical trials also indicate the anti-cancer effect of selenium on the prostate gland. Data from epidemiological, experimental studies on animals and molecular biology data are convergent in terms of the anti-cancer function of selenium. The obtained data indicate that there are essentially two models of selenium's anti-cancer effect: firstly, the functional model is related to the fact that selenium is a micronutrient that provides catalytic centres for numerous selenoenzymes, including antioxidant and reductive-oxidative functions; while the other model sees selenium as a source of selenium metabolites which act differently. To obtain the maximum protective effect of selenium in the prevention of cancer, selenium supplementation should start at an early stage of life and should be maintained throughout life.

\section{References:}

1. Gać P, Pawlas K. Stężenie selenu we krwi w różnych populacjach osób zdrowych i chorych - przegląd piśmiennictwa z lat 2005-2011. Medycyna Środowiskowa 2011; 14(1): 93-104 (in Polish).

2. Langauer-Lewicka H, Pawlas K. Selenium in the environment. Environmental Medicine 2016; 19(1): 9-16.

3. Höghberg J, Alexander J. Selenium. Handbook on the toxicology of metals. 3ed. Academic Press Inc. N.Y. 2007.

4. Ip C, Dong Y, Ganther HE. New concepts on selenium chemoprevention. Cancer Metastasis Rev. 2002; 21(3-4): 281-289.

5. El-Bayoumy K. The negative results of the SELECT study do not necessarily discredit the selenium-cancer prevention hypothesis. Nutrition and Cancer. 2009; 61(3): 285-286. https://doi.org/10.1080/01635580902892829

6. LiY,TollfsbodTO.ImpactonDNAmethylationincancerpreventionand therapybybioactivedietarycomponents. Current Medicinal Chemistry. 2010; 17: 2141-2145. https://doi.org/10.2174/092986710791299966

7. Willett WC, Stampfer MJ. Selenium and cancer. Br. Med. J. 1988; 297 (No 6648): 573-574.

8. Willett WC, Morris JS, Pressel S, Taylor JO, Polk FB, Stampfer MJ, et al. Prediagnostic serum selenium and risk of cancer. Lancet 1983; 322(8342): 130-134. https://doi.org/10.1016/s0140-6736(83)90116-2

9. Zeng H, Combs GF. Jr. Selenium as an anticancer nutrient: roles in cell proliferation and tumour cell invasion. J. Nutr. Biochem. 2008; 19: 1-7. https://doi.org/10.1016/j.jnutbio.2007.02.005.

10. Yu B, Wu J, Zhou X. Interference of selenium, germanium and calcium in carcinogenesis of colon cancer. Chung - Hua - Wai - Ko - Tsa - Chin. 1995; 33: 167-174. 
11. Reddy BS, Tanaka T. Interactions of selenium deficiency, vitamin E, polyunsaturated fat, and saturated fat on azoxymethane - induced colon carcinogenesis in male F344 rats. J. Natl. Cancer Inst. 1986; 76: 1157-1162. https://doi.org/10.1093/jnci/76.6.1157

12. Mikac-Devic M, Vukelic N, Kljaic K. Serum selenium level in patients with colorectal cancer. Biol. - Trace Elem. Res. 1992; 33: 87-94. https://doi.org/10.1007/bf02783996

13. Clark LC, Hixon LJ, Combs GF, Jr., Reid ME, Turnbull BW, Sampliner RE. Plasma selenium concentration predicts the prevalence of colorectal adenomatous polyps. Cancer Epidemiol. Biomarker Prev. 1993; 2: 41-46.

14. Zhuo H, Smith AH, Steinmaus G. Selenium and lung cancer: a quantitative analysis of heterogeneity in the current epidemiological literature. Cancer Epidemiol. Biomarkers Prev. 2004; 13: 771-778.

15. Schober SE, Comstock GW, Helsiêng KJ, Salkeld AE, Morris JS, Rider AA, et al. Serologic precursors of cancer. I. Prediagnostic serum nutrients and colon cancer risk. Amer. J. Epidemiol. 1990; 126: 1033-1044.

16. Nelson RL, Daris FS, Sutter E, Kihendall JW, Sabin LH, Milner JA, et al. Serum selenium and colonic neoplastic risk. Dis. - Colon - Rectum 1995; 38: 1306-1310. https://doi.org/10.1007/bf02049157

17. Medina D, Lane H.W. Stage specificity of selenium mediated inhibition of mouse mammary tumorigenesies. Biol. Trace. Elem. Res. 1983; 5: 297-206. https://doi.org/ 10.1007/BF02987215.

18. Ou Y, Jiang B, Wang X, Ma W, Guo J. Selenium and colorectal adenomas risk: a meta-analysis. Nutr. Cancer 2012; 64: 1153-1159. https://doi.org/10.1080/01635581.2012.722248

19. Knekt P, Marniemi J, Teppo L, Heliövaara M, Aromaa A. Is low selenium status a risk factor for lung cancer ? Amer. J. Epidemiol. 1998; 148: 975-982. https://doi.org/10.1093/oxfordjournals.aje.a009574

20. Liu J, Zhong X, Zhou Q, Gao AC, Wang Y. Primary experimental results of methylseleninic acid on the proliferation inhibition and apoptotic induction in human high-metastatic large cell lung cancer cell line L9981. Zhongguo Fei Ai Za Zhi (Chinese) 2006; 9: 103-108.

21. http://docplayer.pl/4710535-Selen-i-rak-marcin-lener-a-katarzyna-jaworska-bieniek-a-magdalenamuszynska-a-b-grzegorz-sukiennicki-a.html (cited: 2017 Oct 06).

22. Jaworska K, Gupta S, Durda K, Muszyńska M, Sukiennicki G, Jaworowska E, et al. A low selenium level is associated with lung and laryngeal cancers. PLoSOne, March 20138 (3):1-6: e59051. https://doi.org/10.1371/journal.pone.0059051

23. Rayman MP. The importance of selenium to human health. Lancet 2000; 356: 233-241. https://doi.org/10.1016/S0140-6736(00)02490-9.

24. Reid ME, Duffield-Lillico AJ, SungaA, Fakih M, Alberts DS, Marshall JR. Selenium supplementation and colorectal adenomas: an analysis of te nutritional prevention of cancer trial. Int. J. Cancer 2006; 118: 1777-1781. https://doi.org/ 10.1002/ijc.21529.

25. Lippman SM, Klein EA, Goodman PJ, Lucia MS, Thompson IM, Ford LG, et al. Effect of selenium and vitamin E on risk of prostate cancer and other cancers: the Selenium and Vitamin E Cancer Prevention Trial (SELECT). JAMA 2009; 301(1): 39-51.

26. Grodzki T, Wójcik J, Jakubowska A, Wójcik R, Muszyńska M, Kubisa B, et al. International Association for the Study of Lung Cancer (IASLC). 15th World Conference on Lung Cancer, October 27th - 30th, 2013, Sydney, Australia. Abstract M011.13. Low selenium serum level is a good preselection factor for patients invited for low dose chest CT lung cancer screening programme. Journal of Thoracic Oncology 2013; 8: 328-334. 